S. D. VARZHAPETIAN ${ }^{1}$, A. G. GULYUK², T. V. STROGANOVA (Zaporizhye, Ukraine)

\title{
DISTRIBUTION OF RECEPTORS TO LECTINS IN THE SCHNEIDER MEMBRANE UNDER VARIOUS ETIOPATHOGENETIC FORMS OF THE YATROGENIC MAXILLAR SINUSITE
}

\author{
${ }^{1}$ SE "Medical academy Postgraduate Education of the Ministry Health of Ukraine"; \\ ${ }^{2}$ Odesa National Medical University; \\ ${ }^{3}$ The Zaporizhias State medical university <sw050773@gmail.com>
}

\begin{abstract}
The development of modern technologies contributes to the increase in the number of iatrogenic diseases. The article presents the distribution of glucoconjugates in the structures of the Schneider membrane under various etiopathogenetic forms of the iatrogenic maxillary sinusitis of dentition.
\end{abstract}

Key words: lectinhistochemistry of the Schneider membrane, iatrogenic maxillary sinusitis, iatrogenic concomitant diseases.

Relevance. Modern stomatology can't be imagined without the use of high technology. There is a constant modernization of this branch of medicine. The development of medical technologies, as one of the reasons for the increase in the number and frequency of iatrogenic diseases, is noted by many modern authors [1, 3, 7].

With the introduction of new methods of treatment, the habitual picture of pathological conditions associated with medical intervention changes. One of the important points in the strategy of the disease investigation is the systematization of its individual forms. Due to the lack of a separate classification, all dental iatrogenic diseases are considered within the framework of generally accepted medical diagnostic protocols. This leads to standardization of treatment of diseases that do not have a common origin and pathogenesis.

A new etiopathogenetic classification of iatrogenic maxillary sinusitis of stomatogen origin included the forms most commonly found in the clinic [4]. In earlier publications, we cited the results of clinical, radiological, ultrasound and morphological studies of the Schneider membrane in these diseases. To study the characteristics of the inflammatory process at the level of carbohydrate compounds (nanolevel), a relatively new lectinhistochemical method was chosen [6]. In recent years, there has been a tendency towards a wide use of lectins as indicators of the depth of changes in tissues in various pathological processes. This, as well as the use of new classes of carbohydrate-containing drugs in medicine, determines the relevance of this method of research [6,8]. Despite the considerable interest of researchers in the study of the carbohydrate code for diseases, there is no information in the scientific literatureon the nature of the distribution of carbohydrate residues in the maxillary sinusitis that developed against the background of thestomatologic manipulation.

The aim of the study was to study in a comparative aspect the expression of the PSA, WGA, LABA, SBA and Con A lectin receptors in the structures of the maxillary sinus mucosa at various etiopathogenetic forms of iatrogenic maxillary sinusitis of stomatologic origin.

Material and methods. Sampling of biomaterial - a portion of the mucous membrane of the maxillary sinus was performed by in $115(100 \%)$ patients, which were distributed according to etiopathogenetic groups of iatrogenic maxillary sinusitis of stomatologic origin [4]. Into the group of infectious-allergic form of iatrogenic maxillary sinusitis (IAFIMS) there were $22(19.1 \%)$ patients who had established a periapical infection of previously treated teeth in the sinus in the etiology of the disease; The group of the mixed form of iatrogenic maxillary sinusitis (MixFINS) included 24 $(20.9 \%)$ patients with a filling material or a fragment of the tooth root in the lumen of the sinus. 
$12(10.4 \%)$ patients who iatrogenic maxillary sinusitis of stomatologicoriginwich of chronic used medication hormones, antibiotics, drugs) were included in the medical form (MFIMS) group. In the group of traumatic form of iatrogenic maxillary sinusitis (TFIMS) - 57 (49.6\%) patients with sinusitis which developed against surgical manipulations in the area of the alveolar process or the body of the upper jaw.

The biopsies were fixed in a $10 \%$ neutral formalin solution for 48 hours. Dehydration was carried out in an ascending battery of alcohols, starting with $50 \%$ ethyl alcohol, as an intermediate medium, a solution of chloroform was used. Then poured a mixture of paraffin: wax: rubber at a rate of $20: 1: 1$. From paraffin blocks on a rotary microtome, 100-150 serial histological sections with a thickness of $5 \mu \mathrm{m}$ were made. For observational microscopy, histological sections were stained with hematoxylin and eosin. The preparations were processed using the standard sets of "Lectinotest", Lviv in the dilution of lectin1:50 according to the recommended procedure [5].

Visualization of binding sites lectin was carried out in the system diaminobenzidine - hydrogen peroxide. Control of the specificity of the reaction was carried out by eliminating diaminobenzidine from the treatment regimen. Specificity of lectins to terminal non-reducing monosaccharide residues of glycoconjugates is given according to literature data: lectin of "golden shower" (LABA), specific for $\alpha \mathrm{L}-$ fucose $(\alpha \mathrm{L}-\mathrm{Fuc})$; lectin of soybean (SBA), specific for $\mathrm{N}$-acetyl-D-galactosamine ( $\alpha$-NAcDGal); lectin of wheat germ (WGA), specific for $\mathrm{N}$-acetylneuraminic acid (NAcDGlc $\rightarrow$ NAcNeu); lectin of pea (PSA) - to $\alpha$ D-glucose (C6H12O6), lectin of Concavalin A (Con A) - to $\alpha$-mannose $-\mathrm{R}$ [2]. The abbreviated name of lectins is given in accordance with the international nomenclature of lectins [2,9]. The intensity of staining of sections with lectins was evaluated by a semi-quantitative method: "+++" - intensive reaction (brown color); "++" - moderate reaction (golden brown color); "+” - weak reaction (golden yellow color); 0 - no reaction.

The photodocumentation was carried out using a computerized analysis system consisting of an Axiolab binocular microscope, an Axiocam digital video camera with an 8 megapixel matrix, a video adapter connected to a microscope, a personal computer equipped with a video capture card connected to a digital camera via an interface and a video cable and the software "AxioVision 4.8", allowing you to view the image of the histological preparation on the screen in real time, select the necessary area for the photographs to obtain a digital image of the histological preparation, to save it on the hard disk of the personal computer.

The study was conducted with the participation of DM., prof. Grigorieva E. A. Department of human anatomy, operative surgery and topographic anatomy of ZSMU.

Results of the study. Expression of residues of $\alpha$ D-glucose (PSA) in cilia (C. C.) and in the composition of intracytoplasmic granules of the ciliated epithelium of the Schneider membrane of the patients of IAFIMS, MixFIMS and MFIMS was insignificant (+). In the ciliated (C. C.) and goblet cells (Gob. C) of the patients of the TFIMS were for sites lacking PSA + compounds and areas with light yellow color $(0 /+)$. In the composition of intra-cytoplasmic inclusions, Gob.C.in the mixed form of iatrogenic maxillary sinusitis (MixFIMS), the content of PSA + compounds was higher $(++)$ than in the other three study groups. The basal membrane (Bas. M.) and the thin fibers of the own plate of the patients IAFIMS, MixFINS, MFIMS were painted in golden yellow $(+)$. In group TFIMS, Bas.M was colored unevenly: the areas free from the accumulation of the benzidine tag $(0)$ alternated with a golden yellow color $(+)$. Thin fibers of the self-lamina in all groups contained a small amount of $\alpha \mathrm{D}$-glucose $(+)$. Intensive $(+++)$ expression of this compound was found in fibroticaltered thick fibers of self-lamina of the mucous membrane at MixFIMS, versus the average degree of saturation $(++)$ in IAFIMS, MFIMS, and TFIMS.

The intensity of the distribution of wheat lectin (WGA) receptors in ciliated (C.C.) and goblet (Gob. C.) cells of the mucosa of the maxillary sinuses was uneven in MixFIMS and TFIMS: the sites devoid of the carbohydrate residue (0) alternated 
with weak expression $(+)$. At the same time, in the MixFIMS group, the areas with WGA +- combinations $(+)$ prevailed over WGA-negative sections $(0)$. In the Gob.C. TFIMS, on the contrary, there were more WGA-negative sites (0). In C. C. patients IAFIMS and MFIMS the distribution of WGA + - compounds was uniform - the color is light, golden yellow $(+)$.

In all forms of iatrogenic sinusitis, except for MFIMS, the concentration of receptors to WGA in Bas. C. was equivalent and moderate $(+)$. In MFIMS there are marked golden brown areas $(++)$. All patients Bas. M. practically didn't contain WGA + connections.

The latter were found in the infiltrate and on the membrane of the endotheliocytes of the vessels of the propria of the mucous membrane in the normal fibers of the own plate, the IAFIMS, MFIMS and TFIMS of the receptor for the lectin of the wheat (WGA) - the residues NAcDGlc $\rightarrow$ NAcNeu, were not identified. In the MixFIMS, the presence of carbohydrate residues $(+/ 0)$ was noted in places. In foci of fibrosis, the color intensity increased markedly $(++)$ in all groups, except for MixFIMS $(+/ 0)$. WGA + cells, among which lymphocytes and plasma cells are noted, were found in the infiltrate in all preparations. The wall of blood vessels is WGA +.

Table 1. The intensity of the distribution of lectin receptors in the mucous membrane of the maxillary sinus

\begin{tabular}{lcccccc}
\hline \multirow{2}{*}{$\begin{array}{l}\text { The investigated structure of } \\
\text { mucous membrane }\end{array}$} & \multirow{2}{*}{$\begin{array}{l}\text { Name } \\
\text { lectin }\end{array}$} & \multicolumn{4}{c}{ Study groups of iatrogenic maxillary sinusitis } \\
\cline { 3 - 6 } Ciliated & PSA & & + & + & + & $0 /+$ \\
& WGA & + & $+/ 0$ & + & $0 /+$ \\
& LABA & ++ & ++ & + & +++ \\
& SBA & ++ & + & ++ & + \\
& ConA & ++ & $+/ 0$ & + & ++ \\
Basalcells & PSA & + & + & + & $+/ 0$ \\
(Bas. C.) & WGA & + & + & $++/+$ & + \\
& LABA & + & + & ++ & ++ \\
& SBA & + & + & + & $0 /+$ \\
Gobletcells & ConA & + & + & + & + \\
(Gob. C) & PSA & + & + & + & $+/ 0$ \\
& WGA & + & $+/ 0$ & + & $+/ 0$ \\
& LABA & + & ++ & ++ & ++ \\
& SBA & + & ++ & + & $0 /+$ \\
Basal membrane & ConA & + & $+/ 0$ & + & ++ \\
(Bas. M.) & PSA & + & + & + & $0 /+$ \\
& WGA & 0 & 0 & 0 & 0 \\
& LABA & $+/++$ & + & 0 & $+/++$ \\
& SBA & 0 & 0 & $0 /+$ & 0 \\
& ConA & 0 & + & + & + \\
\hline
\end{tabular}

As can be seen from table 1, the difference in the distribution of the carbohydrate residues of L-fucose (LFuc) -receptor to lectin of "golden shower" (LABA) was expressed in patients of the study groups. Aexpressed accumulation of L-fucose $(+++)$ was detected in C. C. with MixFIMS and TFIMS.

The apical sections of the cytoplasm and the apical surface of the ciliated cells were more intensely colored than the basal ones. C. C. in IAFIMS were painted in golden- brown $(++)$, in MFIMS - in golden yellow $(+)$. The intensity of the presence of LABA + compounds in Bas.C.in IAFIMS and MixFIMS was weak $(+)$, in MFIMS and TFIMS - medium intensity $(++)$. Were painted in yellow $(+)$ Gob.C. in the group IAFIMS. In the remaining groups, the color of Gob. C. was more satu- 
rated - golden brown $(++)$, indicating a change in the properties of secretion and mucus, in general. The color of the fibers of the propria of the mucous membrane was uniform and golden-yellow (+) only in the MixFIMS group, the color didn't change in the fibrosis foci. In the remaining groups, the enhancement of accumulation of the benzidine tag in the foci of fibrosis of the intrinsic plate was traced, in contrast to the areas with normal fibers. In the epithelial cells of the glands of the own plate of the mucous membrane, the color of the cytoplasm was also uneven. LABA + contents were found in the lumen of the glands, in the walls of the lymphatic and blood vessels.

The expression of receptors for soy lectin (SBA) was revealed in C. C. $(++)$ and Gob. C. (+) IAFIMS and MFIMS; in Bas. C. (+) - IAFFMS, MixFIMS and MFIMS; in C. C. $(+)$-MixFIMS and TFIMS.some parts of Bas. M. was SBA-positive only in the medical form of iatrogenic maxillary sinusitis (MFIMS), which is associated with the prescription of the medicines (more than 10 years) in patients of this group. The unaltered fibers of the self-lamina in all groups were SBA-negative.

Fibrosis centers of the own plate of patients of the IAF group did not contain receptors for soy lectin (SBA) (Table 2$)$. In the MixFIS group, yellow $(+)$ staining of the fibers was found, in the MFIMS and TFIMS groups - golden brown $(++)$.

Table 2. The intensity of the distribution of lectin receptors in the fibers of the lamina propria of the maxillary sinus mucosa

\begin{tabular}{|c|c|c|c|c|c|c|c|c|}
\hline \multirow{2}{*}{$\begin{array}{l}\text { Name } \\
\text { lectin }\end{array}$} & \multicolumn{8}{|c|}{ Study groups of iatrogenic maxillary sinusitis } \\
\hline & \begin{tabular}{|c|}
$\begin{array}{c}\text { normalfi- } \\
\text { bers }\end{array}$ \\
\end{tabular} & $\begin{array}{c}\text { in the focus } \\
\text { of fibrosis } \\
\end{array}$ & $\begin{array}{c}\text { normal- } \\
\text { fibers } \\
\end{array}$ & $\begin{array}{c}\text { in the focus } \\
\text { of fibrosis } \\
\end{array}$ & $\begin{array}{c}\text { normal- } \\
\text { fibers } \\
\end{array}$ & $\begin{array}{c}\text { in the focus } \\
\text { of fibrosis } \\
\end{array}$ & $\begin{array}{c}\text { normal- } \\
\text { fibers } \\
\end{array}$ & $\begin{array}{c}\text { in the focus of } \\
\text { fibrosis } \\
\end{array}$ \\
\hline PSA & + & ++ & + & +++ & + & ++ & + & ++ \\
\hline WGA & 0 & ++ & $+/ 0$ & $+/ 0$ & 0 & ++ & 0 & ++ \\
\hline $\mathrm{SBA}$ & 0 & 0 & 0 & 0 & 0 & ++ & 0 & ++ \\
\hline Con A & + & + & + & ++ & + & ++ & + & + \\
\hline
\end{tabular}

Thus, the concentration of receptors for lectins LABA, SBA, ConA $(++)$ is expressed in the ciliated cells of the Schneider membrane in IAFIMS. In MixFIMS and TFIMS - to the lectin LABA $(+++)$, in MFIMS - to lectin SBA $(++)$. In the basal membrane in IAFIMS and MixFIMS, the receptors to the lectins studied were weakly expressed $(+)$. The concentration of receptors for the lectin LABA $(++)$ is isolated under MFIMS and TFIMS. In goblet cells of the Schneider membrane of patients with IAFIMS, the carbohydrate residues-receptors to the studied lectins are weakly expressed, with the same density $(+)$. In MixFIMS, the receptors for LABA and SBA $(++)$. In MFIMS to LABA and ConA $(++)$. In TFIMS - only to lectins LABA $(++)$.

In the basal membrane, the presence of receptors for LABA $(+/++)$ is relatively expressed in the IAFIMS and TFIMS groups. In the altered fibers of the intrinsic plate of the Schneider membrane, the expression of the receptors of the lectins studied was most often recorded with high intensity in the TFIMS group, with a low intensity in the MixFIMS group.

Conclusions. 1. With different etiopathogenetic forms of iatrogenic maxillary sinusitis, differences in the expression of individual glycoconjugates in the structures of the Schneider membrane were revealed. 2. For various forms of iatrogenic maxillary sinusitis of stomatogen origin, the expression of receptors to the lectin of a leaves "Golden shower" (LABA) is most pronounced.

\section{Спи сок лит ературы}

1. Авдеев А. И., Козлов С. В. Ятрогенные заболевания (медико-правовые аспекты) //
1. Avdeev A. I., Kozlov S. V. Yatrogennyie zabolevaniya (mediko-pravovyie aspektyi) // 
Дальневосточный мед. журн. - 2009. С. 113-116.

2. Антонюк В. О. Лектини та їх сировинні джерела. - Львів: ПП «варт», 2005. $554 \mathrm{c}$.

3. Баринов Е.Х., Ромодановский П. О. Судебномедицинская экспертиза профессиональных ошибок и дефектов оказания медицинской помощи в стоматологии. - М.: НП ИЦ «ЮрИнфоЗдрав», 2012. - 204 с.

4. Гулюк А. Г., Варжапетян С.Д. Обоснование классификации ятрогенных верхнечелюстных синуситов стоматогенного происхождения // Інновації в стоматології. 2015. -№ 2. - С. 27-38.

5. Луиик А. Д., Детюк Е.С., Луцик М. Д. Лектины в гистохимии. - Львов: Выща шк., 1989. - $144 \mathrm{c}$.

6. Титов Д. В., Генинг М.Л., Цветков Ю. Е., Нифантьев Н. Э. Конъюгаты циклоолигосахаридных матриц с углеводными лигандами: методы синтеза и взаимодействие с лектинами // Биоорганическая химия. 2013. - Т. 39, № 5. - С. 509-546.

7. Янушевич О. О., Баринов Е. Х., Добровольская H. E. и др. Судебно-медицинская и медико-правовая оценка неблагоприятных исходов в стоматологической практике / Под ред. О. О. Янушевича. - М.: ГЭОТАР-Медиа, 2016. - 384 с.
Dalnevostochnyiy med. zhurn. - 2009. S. 113-116.

2. Antonyuk V. O. Lektini ta Yih sirovinni dzherela. - Lviv: PP «Kvart», 2005. $554 \mathrm{~s}$.

3. Barinov E. H., Romodanovskiy P. O. Sudebno-meditsinskaya ekspertiza professionalnyih oshibok i defektov okazaniya meditsinskoy pomoschi v stomatologii. - M.: NP ITs «YurInfoZdrav», 2012. - 204 s.

4. Gulyuk A. G., Varzhapetyan S. D. Obosnovanie klassifikatsii yatrogennyih verhnechelyustnyih sinusitov stomatogennogo proishozhdeniya // InnovatsiYi v stomatologiyi. - 2015. - \# 2. - S. 27-38.

5. Lutsik A.D., Detyuk E.S., Lutsik M.D. Lektinyi v gistohimii. - Lvov: Vyischa shk., 1989. - $144 \mathrm{~s}$.

6. Titov D. V., Gening M.L., Tsvetkov Yu.E., Nifantev N. E. Kon'yugatyi tsiklooligosaharidnyih matrits s uglevodnyimi ligandami: metodyi sinteza i vzaimodeystvie s lektinami // Bioorganicheskaya himiya. - 2013. T. 39, \# 5. - S. 509-546.

7. Yanushevich O. O., Barinov E. H., Dobrovolskaya N. E. i dr. Sudebno-meditsinskaya i mediko-pravovaya otsenka neblagopriyatnyih ishodov v stomatologicheskoy praktike / Pod red. O. O. Yanushevicha. - M.: GEOTAR-Media, 2016. - $384 \mathrm{~s}$.

8. Bog-Hansen T. C., Spengler G. A. Lectin biology, biochemistry, clinical biochemistry // Proc. V lectin meeting. - 1983. - Vol. 3. - P. 87-327.

9. Lee R. T., Lee Y. C. San Diego // Neoglycoconjugates: Preparation and Applications. - Acad. Press, 1994. - P. 23-50.

\section{РОЗПОДІЛ РЕЦЕПТОРОВ ДО ЛЕКТИНІВ У МЕМБРАНІ ШНАЙДЕРА ПРИ РІЗНИХ ЕТІОЛОГІЧНИХ І ПАТОГЕНЕТИЧНИХ ФОРМАХ ЯТРОГЕННОГО ВЕРХНЬОЩЕЛЕПНОГО СИНУСИТУ}

\section{С. Д. Варжапетян, А. Г. Гулюк, Т. В. Строгонова (Запоріжжя)}

3 розвитком сучасних технологій в стоматології відмічається збільшення кількості ятрогенних захворювань. У статті наведено дані про розподіл глюкокон'югатів - рецепторів до лектиніву в структурах мембрани Шнайдера при різних етіологічних і патогенетичних формах ятрогенного верхньощелепного синуситу стоматогенного походження.

Ключові слова: лектингістохімія мембрани Шнайдера, ятрогенний верхньощелепний синусит, ятрогенні супутні захворювання.

\section{РАСПРЕДЕЛЕНИЕ РЕЦЕПТОРОВ К ЛЕКТИНАМ В МЕМБРАНЕ ШНАЙДЕРА ПРИ РАЗЛИЧНЫХ ЭТИОЛОГИЧЕСКИХ И ПАТОГЕНЕТИЧЕСКИХ ФОРМАХ ЯТРОГЕННОГО ВЕРХНЕЧЕЛЮСТНОГО СИНУСИТА}

\section{С. Д. Варжапетян, А. Г. Гулюк, Т. В. Строгонова (Запорожье)}

С развитием современных технологий в стоматологии отмечается увеличение количества ятрогенных заболеваний. В статье приведены данные о распределении глюкоконюгатов - рецепторов к лектинам, в структурах мембраны Шнайдера при различных этиологических и патогенетических формах ятрогенного верхнечелюстного синусита стоматогенного происхождения.

Ключевые слова: лектингистохимия мембраны Шнайдера, ятрогенный верхнечелюстной синусит, ятрогенные сопутствующие заболевания. 